\title{
The Development of Growth Model with the Implication of Crisis Regime
}

\author{
Mohd Shahrol Nizam \& Norimah Rambeli \\ Faculty of Management \& Economics, University Pendidikan Sultan Idris, Perak, Malaysia \\ shahrol2014upsi@gmail.com, norimah@fpe.upsi.edu.my
}

\begin{abstract}
This conceptual paper aims to develop the theory of growth proposed by Keynes by considering crises or events that occur as well as incorporating interaction variables into the model to be studied simultaneously. Studies related to growth theory have been conducted before. However, previous studies have ignored crises or important events that affect economic growth. Although the Keynesian theory has been used to achieve the objectives of the study, past studies have proven that Wagner's Law may exist in some situations. Therefore, the opinions of these two economic figures related to the theory of government expenditure and economic growth should be given attention. The main objective of this conceptual paper was to assess the relationship between interactional variables and dummy variables of structural change in three regimes or different crises occurring simultaneously and the effects on economic growth in Malaysia for the long-term and short-term periods. The Autoregressive Distributed Lag (ARDL) method will be used to ascertain long-term and short-term relationships between endogenous and exogenous variables. Then, the results from previous studies are included in the findings section of the study.
\end{abstract}

Keywords: Government expenditure, economic growth, Autoregressive Distributed Lag (ARDL), Keynesian theory, Wagner's law.

\section{Introduction}

Malaysia has experienced economic crises or structural changes that resulted from external factors such as the open economic policy is practiced. Some other crises that occurred were the 1985 Commodity Price Drop, the 1991 Fuel Price Decline, the 1997-1998 Asian Financial Crisis, the 2008 Global Financial Crisis and the 2020/2021 Global Health Crisis. Of all the crises, 2020/21 Global Health Crisis has affected the economic growth of not only Malaysia but also other nations around the world. Nonetheless, Malaysia has managed to overcome the crisis via specific policies. For example, the implementation of an expansionary fiscal policy can both restore and increase the country's GDP. This has been proven when the country faced the Asian Financial Crisis and the Global Financial Crisis (Kaharudin et al., 2017). John Maynard Keynes was an economist who put forward the Keynesian theory regarding the law of demand and supply. Then came Adolph Wagner, who introduced Wagner's Law. Keynes has clearly presented an equation for looking at the relationship between dependent and independent variables.

Unlike Keynes, Wagner did not provide a specific formula for measuring the relationship between these two variables and was only based on the view that there is a natural tendency to increase government spending when economic growth occurs. Further implications from the study of Wagner's Law have given rise to various versions of the law. Additionally, many empirical studies and dynamic relationships have been conducted to answer the questions that arise, especially about the role of government spending itself on economic growth. Modifications to the original theory put forward by Keynes aim to study the dynamic relationship between selected macroeconomic variables and economic growth based on different structural changes (crises) and interaction terms in the long and short term simultaneously. Meanwhile, Gross Domestic Product (GDP) is regarded as an endogenous variable. Exogenous variables included government expenditure, population, foreign direct investment, net exports, dummy variables, and interactional variables.

\section{Crisis during the Study Period}

A crisis is defined as an uncontrollable or unstable economic situation that can bring a negative effect (Kamus, 2005). As mentioned previously, Malaysia has faced a crisis which gives a negative effect on the economy and the effects can still be felt to this day. The present study involved the formation of a dynamic relationship model based on structural change or shocks whereby each model formed was divided into a few phases of 
structural change. As such, this section would explain the three series of main crises or shocks which occurred during the study period.

Figure 1: Malaysian Economic Crisis Timeline

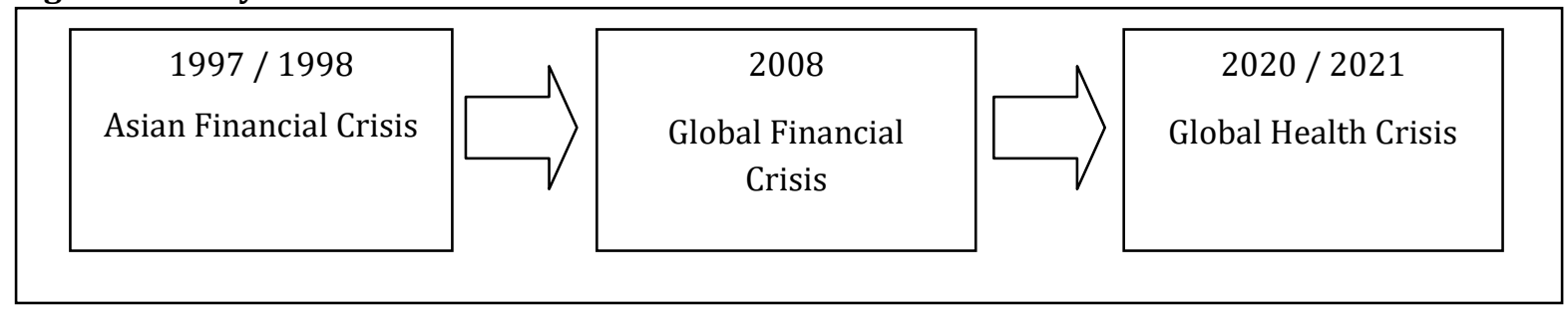

1997/1998 Asian Economic Crisis: The Asian economic crisis started in Thailand. This happened when speculators caused the Thai national currency to collapse and led to a massive outflow of capital. In January 1998, the value of the Thai currency was 56 Baht to 1 US Dollar. Previously, the value was 25 Baht from 1986 to July 1997 (Sharma, 2003). This crisis gave a negative effect on Malaysia whereby its economic growth had reached a negative value in 1998. Other Asian countries were also affected by this crisis which was described as the worst crisis at that time. It also affected the currency value in countries such as South Korea. Additionally, this situation also affected other macro-economic variables such as international investment, service, and trade. This is because the economies of other countries also had a close relationship with the economies in Asian countries. To overcome this crisis, two mechanisms had been implemented which was by increasing the government expenditure for certain sectors and pegging the ringgit value to the US Dollar at the rate of RM3.80 per dollar (Bank Negara Malaysia, 1998). The fall of the ringgit was also related to the depreciation of shares (World Bank, 2018).

The Global Economic Crisis of 2008: Although the Malaysian economy managed to recover in the following year as indicated from the GDP increase from 6.1 percent in 1999 to 8.9 percent in 2000, Malaysia was again affected by the Global Economic Crisis. In 2009, the Malaysian economy experienced a decline of 2.5 percent caused by the 2008 crisis. However, the GDP managed to rise in 2010. This was made possible due to the mechanism in increasing government expenditure via the expansionary fiscal policy. In line with the budget allocated for 2010, the expenditure was specified for management and development spending. The Overnight Policy Rate Adjustment (OPR) was also adopted to avoid financial imbalance, disproportionate risks, prevent the financial transmission process and long-term growth capabilities from being affected (Wijaya, Noorasiah \& Liew, 2011). Malaysia was not directly affected by the crisis; nonetheless, the effects were evident as the signed Free Trade Agreement involved imports and exports between Malaysia and the United States.

The Global Health Crisis of 2020/2021: Malaysia's economic growth recorded negative growth in 2020 at 5.6 percent. This was contrasted with the economic growth in 2019 at 4.3 percent (Bank Negara Malaysia, 2020). The negative growth was like the global economic crisis which occurred in 2008, and this led Malaysia to record economic growth of -6.2 percent. The reason for this severe economic shock was the Covid 19 pandemic which caused a global economic response at an unprecedented scale. This response was significant for preventing far worse deterioration in global economic activities. The response was focused on recovery measures to support the household income, to maintain companies' cash flow, to decrease the number of closed-down and bankrupt companies and to preserve jobs and decrease the long-term economic risks. A total of RM 530 billion had been spent by the government for 8 economic stimulus packages such as Prihatin, Prihatin PKS Tambahan, Penjana, Kita Prihatin, Permai, Pemerkasa, Pemerkasa Plus and Pemulih. This amount had an increase of RM 280 billion compared to the initial amount announced in March 2020 which was 250 billion to provide immediate assistance for people who had been affected by this pandemic. From the amount, some RM 305 billion had been spent which was 22.7 percent of the nation's GDP in 2020. This was considered one of the biggest rates globally compared to the stimulus package implemented in Indonesia, South Korea, and the United States. Thus, it can be concluded that the crises which occurred affected the economic situation in Malaysia. It was also clear that government expenditure was a variable that successfully alleviated economic growth. The crises which happened also affected other macroeconomic variables such as investment, international trade, and labor market components. 
Conceptual Framework: This conceptual framework contains causal factors to the phenomenon being studied, variables, theories that form the basis of the study and how other elements are related to each other. It also describes the inter-relationships of elements that ultimately lead to the main objective of the study. This conceptual framework could be described as the initial description of the inter-relationships of the whole elements. Whether the relationship is proven true or otherwise depends on the study findings. The following is the conceptual framework for this study.

\section{Figure 2: Research Conceptual Framework}

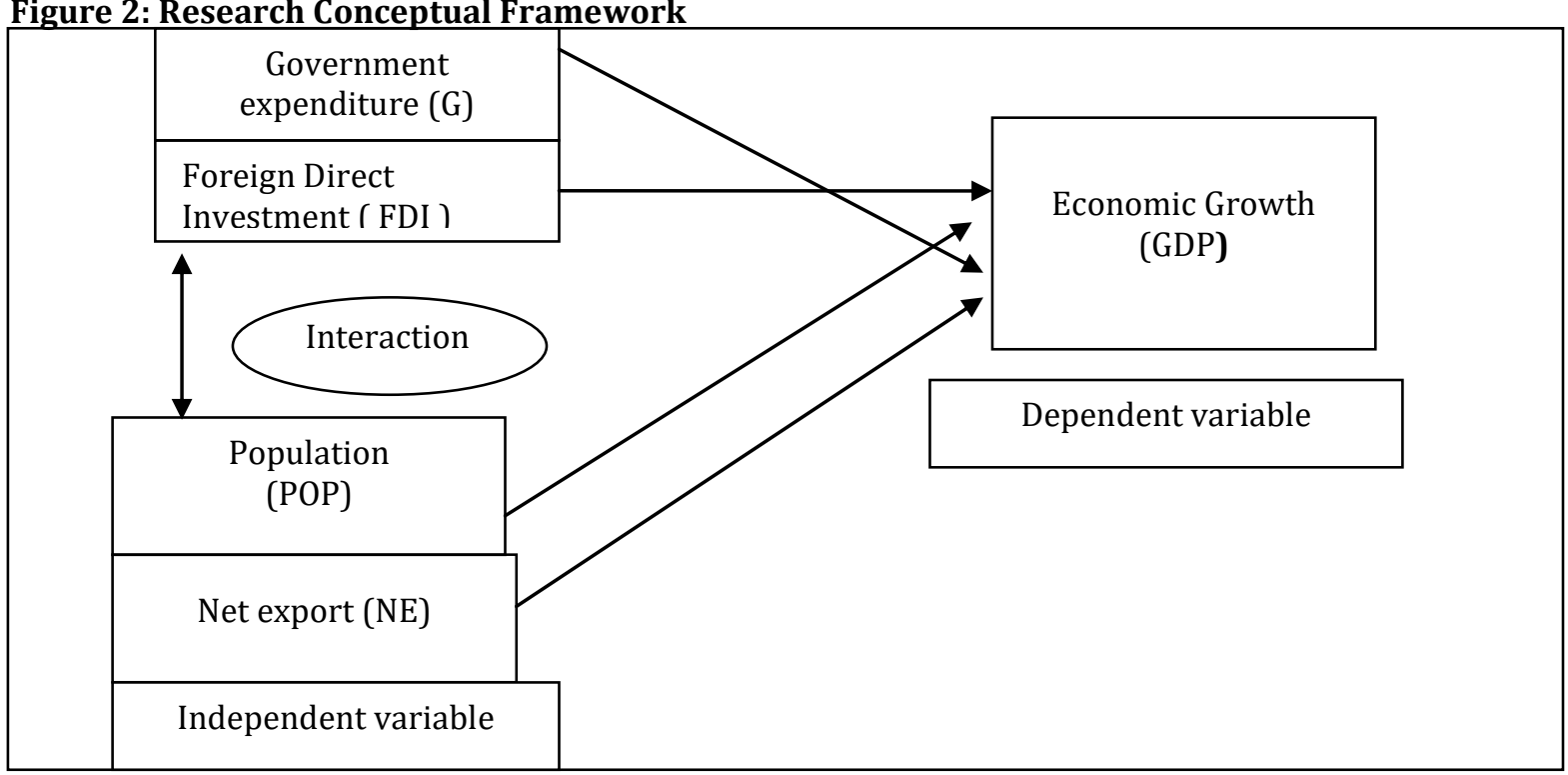

\section{Theoretical Foundation}

Based on the macroeconomic theories, good economic growth is one of the important aspects of a country's development. This occurs when there is an increase in per capita income from year to year (Jespersen, 2005). This study was based on two major economic theories which are the Keynesian theory and Wagner's Law. The main function utilized was based on the Keynesian Theory of Demand and Supply. Additionally, the study was based on previous studies such as Rambeli et al. (2016). These selected macroeconomic variables were included in the model based on their importance and contribution towards economic growth. The hypothesis pioneered by Wagner shows that the general functional relationship between government spending and economic growth (GDP) in a country can be described as the following equation:

$\mathrm{G}=\mathrm{f}(\mathrm{GDP})$.

Where:

$\mathrm{G}=$ Government expenditure

GDP $=$ Gross Domestic Product

In contrast, there is a different interpretation of government expenditure and growth according to the Keynesian view. According to the theory, the nation's income composition is made up of this equation:

$\mathrm{Y}=\mathrm{C}+\mathrm{I}+\mathrm{G}+\mathrm{Xn}$.

Where:

$\mathrm{Y}=$ Economic growth (GDP)

$\mathrm{C}=$ Consumption

$\mathrm{I}=$ Investment

$\mathrm{Xn}=$ Net export (Export minus import)

Nonetheless, this study was also based on other studies such as the one by Rambeli et al. (2016). As such, the basic function used for the Keynesian study would be:

$\mathrm{GDP}=\mathrm{f}(\mathrm{I}, \mathrm{X}, \mathrm{M})$ 
Where:

GDP $=$ Gross Domestic Product (proxy to economic growth)

$\mathrm{I}=$ Investment (Domestic and Foreign)

$\mathrm{X}=$ Export

$M=$ Import

However, function 3 showed that the economic growth from the actual GDP was prone to shocks or crises (Choong, Zolkarnain \& Liew, 2010).

As such, function 3 was modified (function 4) to represent a specific economic crisis by including the dummy variable (DUM) in which the zero value was utilized before and after the crisis period and the value of one (1) was utilized during the crisis period. The function could be written as such:

KDNK = $\mathrm{f}(\mathrm{GE}, \mathrm{POP}, \mathrm{NE}, \mathrm{FDI}, \mathrm{DUM})$

Where:

GDP = Gross Domestic Product (Proxy to Economic Growth)

$\mathrm{GE}=$ Government expenditure

$\mathrm{POP}=$ Population

$\mathrm{NE}=$ Net export

FDI $=$ Foreign Direct Investment

DUM = Dummy for Structural Change

The empirical model for the assumption after including the interactional variable would be:

$\mathrm{KDNK}=\mathrm{f}(\mathrm{GE}, \mathrm{POP}, \mathrm{NE}, \mathrm{FDI}, \mathrm{DUM}, \mathrm{POP} * \mathrm{NE})$

Where:

GDP $=$ Gross Domestic Product (Proxy to Economic Growth)

$\mathrm{GE}=$ Government expenditure

POP = Population

$\mathrm{NE}=$ Net export

FDI $=$ Foreign Direct Investment

DUM = Dummy for Structural Change

POP*NE = Multiplication of Population and Net Exports

\section{Study Findings}

Previous Studies: Norazarin (2018) studied the dynamic relationship between interactional variables and international trade in two different models and the inclusion of structural change dummy towards economic growth. The findings indicated that there was a two-way relationship between economic growth for longterm and short-term periods using the Vector Error Correction Model (VECM). A study by Kahrudin et al. (2017) included a structural change dummy by considering two important events which occurred in 1997 and 1998 as well as 2007 and 2008 which were related to the Asian Financial Crisis and the Global Financial Crisis. The study which utilized the Structural Vector Autoregressive (SVAR) analysis in Malaysia aimed to assess the fiscal policy effects on the expenditure of private firms. Antonakakis et al. (2017) utilized interactional variables of oil dependency and quality of political institutions towards economic growth variables. In the study by Moradbeigi \& Law (2017), the researchers utilized interactional variables of oil abundance and financial development towards economic growth. The empirical study was conducted to answer whether Financial Development moderates the negative impact of natural resources, especially oil production. There was also research conducted to ascertain the difference in study findings by utilizing the interaction term or otherwise. These studies were conducted by Hakimah et al. (2014) by utilizing the interactional variables.

Between Foreign Direct Investment (FDI) and Stock Market Development Quality. Some studies utilized the dummy variable as an interactional term with other variables. Rosli, et al. (2014) were researchers who conducted such studies. Analysis was carried out on the indicators of efficiency and productivity of firms related to Syariah-compliant and non-compliant consumer products at the Kuala Lumpur Stock Exchange (KLSE). The findings showed that a firm's Syariah-compliant factor and sales factor must work together to influence the company's efficiency. Three basic models were formed which were the Level Transition Model, 
Level Transition Model with the trend and the Regime Transition Model in the study conducted by Kogid et al. (2012) to assess the cointegration relationship in long-term and short-term periods as well as the dynamic interaction between the stock market and economic activities. The important dates mentioned as the transition function were included as dummy variables. Verma \& Arora (2010) utilized the structural change dummy towards the growth of government spending. The structural change here referred to two different phases which were the initial liberalization phase and the intensive liberalization phase in India. The impact of economic reform in the intensive liberalization phase was significant towards the growth of government spending and not towards the initial liberalization phase. Additionally, the change of coefficient of elasticity in the sub-period phase was also seen as important.

Findings from the study by Toh et al. (2010) titled Inflation Threshold and Economic Growth in Malaysia showed that there was a change in the direction of the cause for both variables. The period before and after the crisis would influence the inflation rate whereby the average inflation rate before the crisis would be much higher compared to the period after the inflation. Additionally, the inflation variable in the model was not significant in influencing the economic growth but at the level of the inflation horizon value, the dummy variable was significant in negatively influencing economic growth. Empirical findings from the study by Samudram, Nair \& Vaithilingam (2008) in Malaysia found that structural change caused by the Asian Financial Crisis of 1997 / 1998 was significantly related to the government expenditure towards other macroeconomic variables such as administration and health. The study was conducted to test the Keynesian theory and Wagner's Law. A two-way relationship was found as evidence that the Keynesian theory and Wagner's Law existed in Malaysia. The findings from the study above were in line with the findings from Sarel (1996), whose study involved 87 nations in a study period from 1970 to 1990 . The latter study showed that inflation was not significant in influencing economic growth but there was a negative relationship between inflation and economic growth in situations where inflation exceeded the inflation horizon value. The following table is a summary of previous studies relevant to this study:

Table 1: Summary of Articles Included in Study Findings Based on Structural Change Dummy and Interactional Variable

\begin{tabular}{|c|c|c|c|c|c|}
\hline $\begin{array}{l}\text { Title / } \\
\text { Authors/ } \\
\text { Year }\end{array}$ & Theory / Model & Methodology & $\begin{array}{l}\text { Time } \\
\text { Period }\end{array}$ & Variables & Results \\
\hline $\begin{array}{l}\text { Dynamic } \\
\text { Relationship } \\
\text { Between } \\
\text { Interactional } \\
\text { Variable and } \\
\text { International } \\
\text { Trade } \\
\text { Toward } \\
\text { Economic } \\
\text { Growth in } \\
\text { Malaysia } \\
\text { Norazrin } \\
\text { (2018) }\end{array}$ & $\begin{array}{l}\text { Demand Model \& } \\
\text { Aggregate Supply } \\
\text { by Keynes }\end{array}$ & $\begin{array}{l}\text { Vector Error } \\
\text { Correction } \\
\text { Model (VECM) }\end{array}$ & $\begin{array}{l}\text { January } \\
1979 \\
\text { December } \\
2017\end{array}$ & $\begin{array}{l}\text { Real Gross } \\
\text { Domestic } \\
\text { Product } \\
\text { Export } \\
\text { Import } \\
\text { Real Effective } \\
\text { Exchange Rate } \\
\text { Structural } \\
\text { Change } \\
\text { Dummy } \\
\text { Interactional } \\
\text { Variables }\end{array}$ & $\begin{array}{l}\text { According to the } \\
\text { empirical study, } \\
\text { international } \\
\text { commerce, which } \\
\text { functions as an } \\
\text { endogenous variable } \\
\text { in the long-term } \\
\text { system of equations, } \\
\text { has been proven to } \\
\text { play a vital role in } \\
\text { producing economic } \\
\text { growth. Furthermore, } \\
\text { the findings revealed } \\
\text { long-term and short- } \\
\text { term bidirectional } \\
\text { causality between } \\
\text { interaction variables } \\
\text { and economic growth. } \\
\text { As a result, } \\
\text { fluctuations in the } \\
\text { exchange rate have a } \\
\text { significant impact on } \\
\text { international trade. }\end{array}$ \\
\hline
\end{tabular}


The Effect of Fiscal Policy on Private Expenditure: A SVAR Analysis in Malaysia Kaharudin, et al. (2017)

Oil

Dependence,

Quality of

Political

Institutions

and

Economic

Growth: A

Panel VAR

Approach.

Antonakakis

et al (2017)
Classical Theory \& Keynesian Theory

Structural
Vector
Autoregressive
(SVAR)

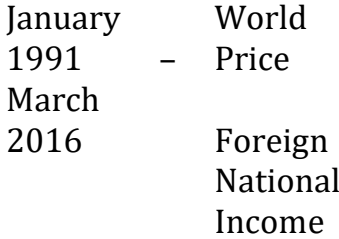

Government

Tax Revenue

Government

Expenditure

Interest Rate

Private

Investment

Private

Consumption

Domestic

Income

Real Effective

Exchange Rate

Structural

Change

Dummy

Keynesian Theory Panel Vector 1980-2012 Gross

Autoregressive

(PVAR)

Domestic

Product

As international trade is such a large source of national income, any exchange rate shocks can still be mitigated by using the interaction variable.

Oil The key findings revealed that government spending shocks were found to crowd out private investment while having a beneficial effect on private consumption. For government revenue shocks, the same results were found, which indicated that private investment had a negative effect, whereas government consumption had a positive effect.

Oil

Dependence

Quality

Political

$$
\text { of for economic poict }
$$

While increases in oil prices driven by real aggregate demand and oil-market specific demand shocks have longterm repercussions

Institutions uncertainty in the United States, supplyside oil shocks have Exogenous little impact in the US. Control The findings suggest Variables that making the resource curse 


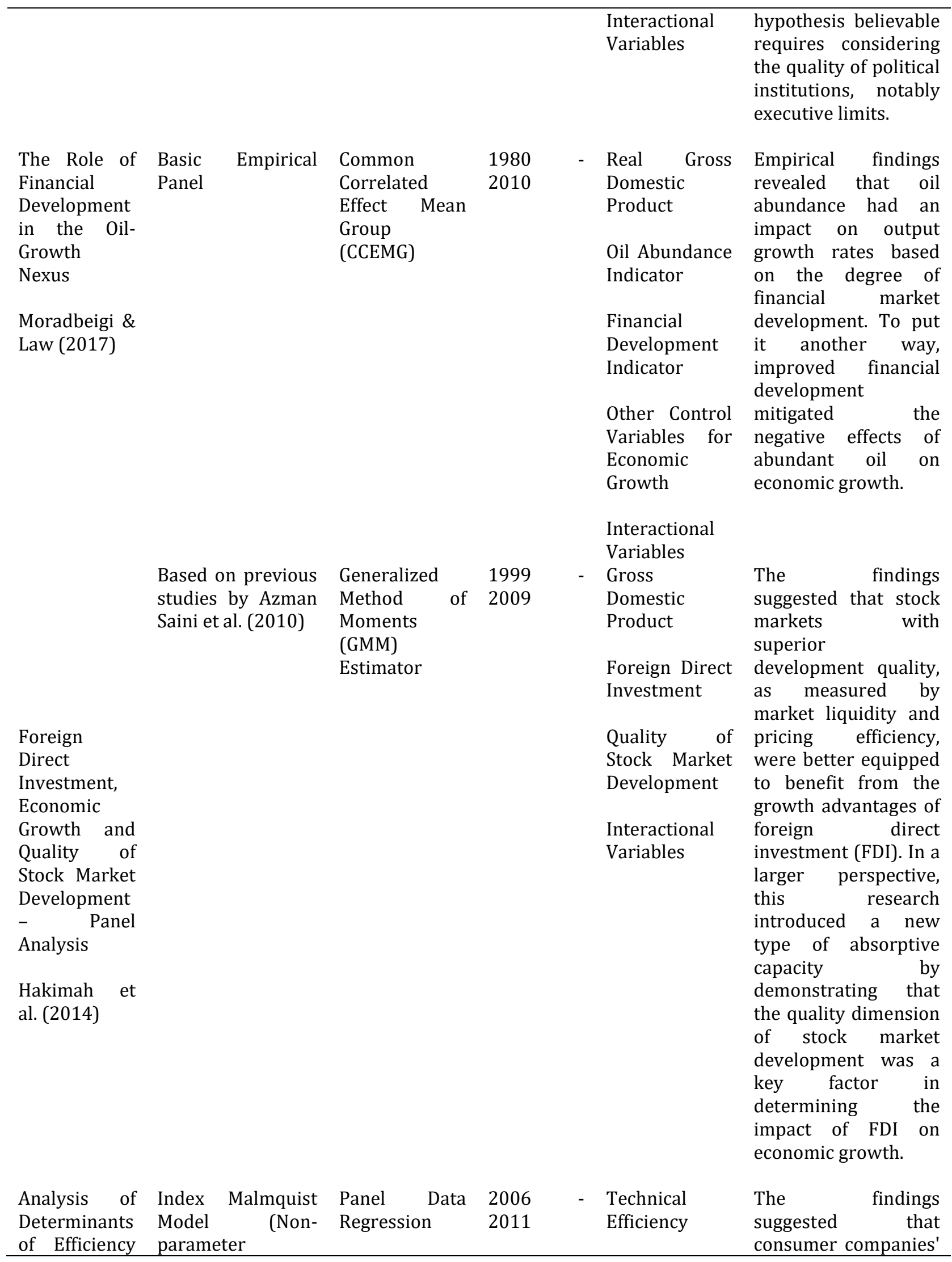




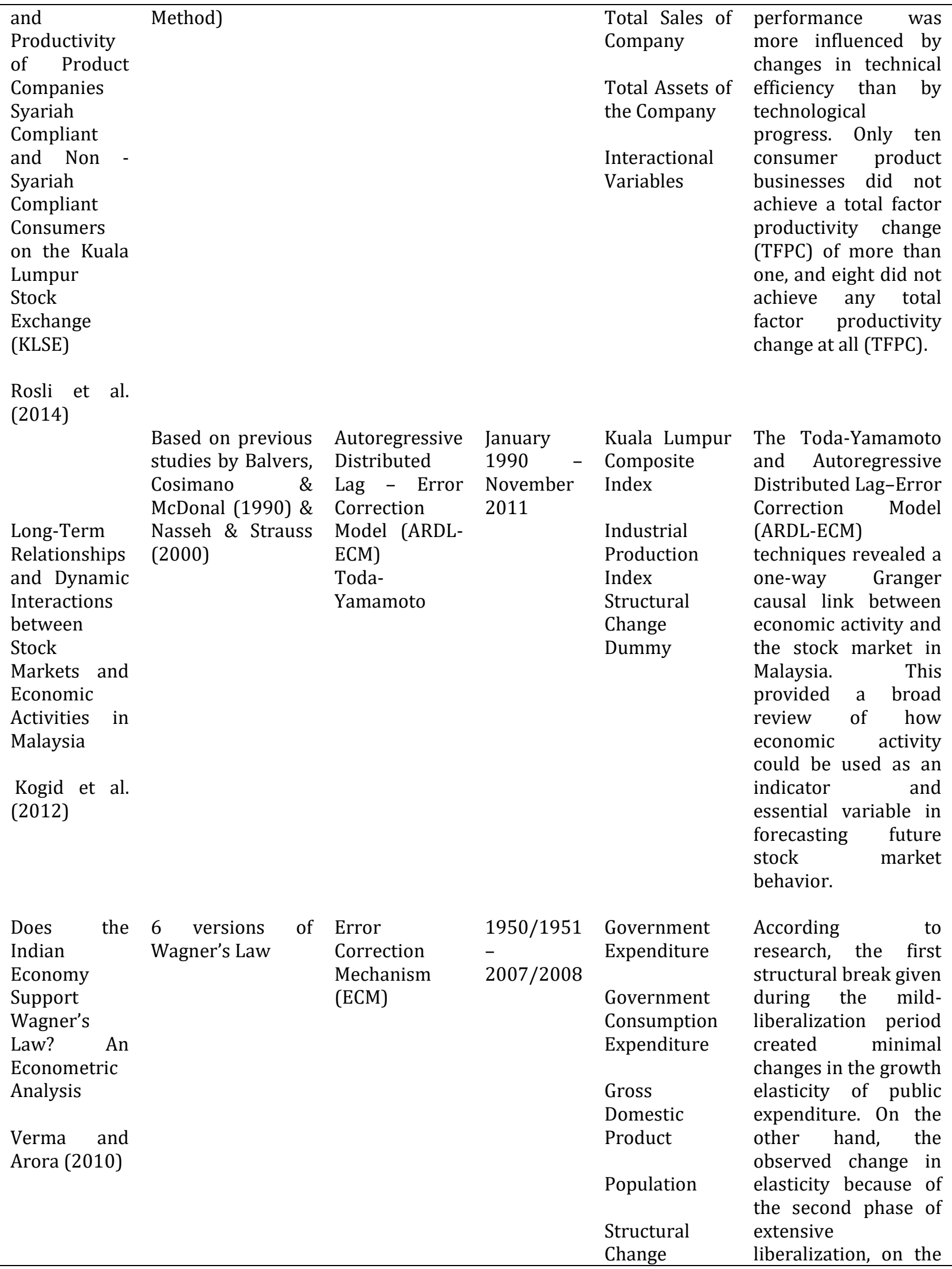




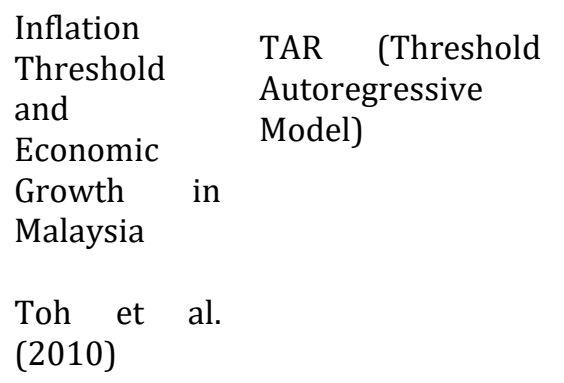

TAR (Threshold Autoregressive Model)

Based on previous studies by Hansen (2000), Khan \& Senhadji (2001)\& Mubarik (2005)

Granger Causality Test

\begin{tabular}{|c|c|c|}
\hline First & & Gross \\
\hline Quarter & & Domestic \\
\hline 1991 & - & Product \\
\hline Fourth & & \\
\hline Quarter & & Inflation Rate \\
\hline
\end{tabular}
2009

Gross Fixed

Capital

Formation

Term of Trade

Rates

Structural

Change

Dummy other hand, was statistically

significant. Despite this, given a large drop in elasticity, Wagner's rule was nevertheless upheld throughout the intensive phase of liberalization. The existence of any relationship between economic growth and the size of government

expenditure was refuted by empirical evidence on short-run dynamics.

The findings suggested that inflation rates above the threshold had a detrimental influence on economic growth, with the yearly inflation threshold value being roughly 3 percent or 0.8 percent for each quarter. These findings served as a foundation for defining an inflation target that did not jeopardize the stability of economic growth.

Keynes and

Keynesian Theory

Autoregressive 1970

Distributed 2004

Wagner on

\& Wagner's Law

Lag (ARDL)

Expenditures

and

Economic

Development:

The Case of

Developing

Economy

Samudram et al. (2008)
Gross National The findings also Product revealed that, following the Administrative structural break in Expenditure 1998, the long-run causality for Gross Health National Product Expenditure (GNP) and administrative and Education health expenses was Expenditure bi-directional, validating both Defense Keynes' and Wagner's Expenditure theories. The long- 


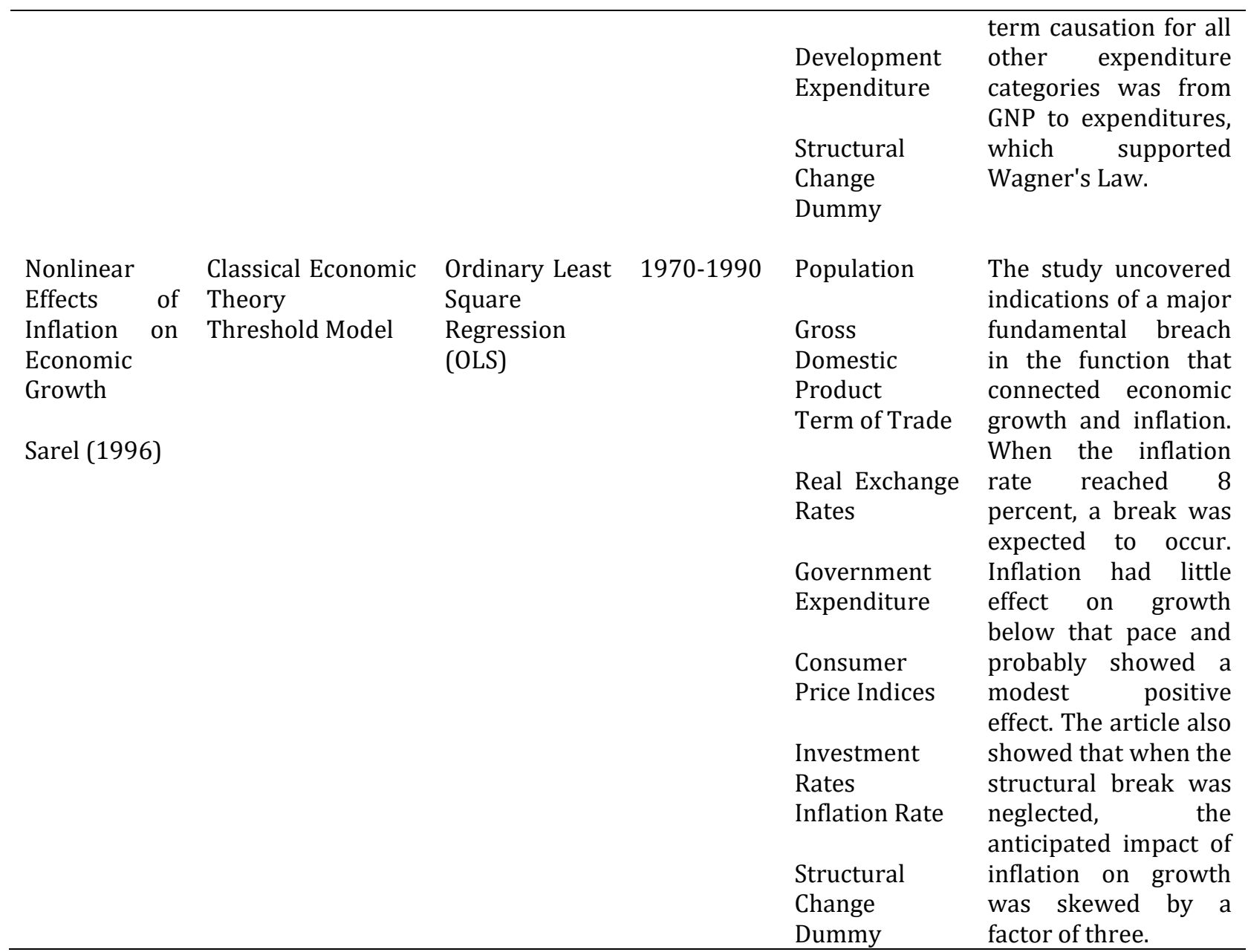

Source: Derived from previous studies for model development purposes.

\section{Methodology}

Time Series Data: Time series data were utilized to achieve the study objectives which were to examine the dynamic relationship between various variables in the system of equations formed in the long-term and short-term on economic growth. According to Sahlan (2021), economic analysis suggests that the variables involved in the economic theory under consideration have a long-run relationship or balance. To estimate these long-run correlations, users of econometric analysis frequently make the implicit assumption that the classical assumptions, i.e., mean and variance values, remain constant and independent across time. In the case of time series variables, however, empirical research has demonstrated that constant mean and variance values do not occur in most cases. As a result, traditional tests like the $t$-test and $F$-test assume that constant mean and variance values are no longer acceptable. It is expected that economic indicators such as gross domestic product, exports, imports, and other factors will be observed throughout time.

These variables are random in nature and cannot be predicted correctly, thus their value cannot be determined until they are observed. A stochastic or random process is the economic model generated by this time series variable, and the realization of the stochastic process is the sample observation for the value of this time series variable. This is one of the various approaches to the stochastic process. Gross domestic product (GDP), aggregate government expenditure (GE), population (POP), foreign direct investment (FDI) and net exports (NE) for a period of 42 years 3 months in monthly form from 1980Q1 to 2021Q3 were collected from various sources for time series analysis such as the Department of Statistic Malaysia (DOSM), Bank Negara Malaysia (BNM) and Ministry of International Trade and Industry (MITI). 
Estimation Method: In analyzing data, many tests have been utilized to obtain accurate findings. For example, Sari and Kaluge (2017) utilized Multiple Linear analyses. Granger Causal Tests in Vector Error Correction Model (VECM) were utilized by (Salwindi \& Seshamani, 2016; Furuoka \& Harvey, 2014; Dada \& Adewele, 2013; Abdullah \& Maamor, 2010). Meanwhile, Afonso \& Alves (2016) utilized Seemingly Unrelated Regression (SUR). Mohammadi \& Ram (2015) utilized Gregory Hansen's Cointegration Test and Pedroni Test. The Autoregressive Distributed Lag (ARDL) test was utilized by (Yudistira et al., 2014; Kumar et al., 2012). Some studies combined more than one test to acquire more accurate and specific findings. For example, Furuoka \& Harvey (2014) utilized the Three Stage Procedure, Ordinary Least Square (OLS) Regression Model, and the Vector Error Correction Model (VECM). Meanwhile, Sinha (2007) utilized the Toda-Yamamoto, Autoregressive Distributed Lag (ARDL) and the Ng-Perron test. Studies involving structural change were conducted by Verma \& Arora (2010) and Samudram et al. (2008). This study applied the Autoregressive Distributed Lag (ARDL) method as suggested by Pesaran et al. (2001) to analyze the relationship between Government Expenditure (GE), Population, (POP), Net Export (NE), Foreign Direct Investment (FDI) and Gross Domestic Product (GDP). Other tests conducted were the Unit Root Test and Granger Causality Test to assess the dynamic relationships between the interactional variables and selected macroeconomic variables towards economic growth in Malaysia in short-term and long-term periods.

The ARDL is an econometric method that allows model estimation to be done regardless of whether a time series variable reaches stationary at level $I(0)$ or differential $I(1)$ or a combination of time series variables that reach stationary at $I(0)$ and $I(1)$. An advantage of using the Autoregressive Distributed Lag (ARDL) is that the method does not require the stationary test to be conducted on time series data. As such, the cointegration test was conducted to assess if long-term and short-term relationships were feasible. The cointegration relationship could be ascertained easily in small sample sizes involving 30 to 80 years of observation. It allows the cointegration relationship to be identified for variables with different optimum lags. The estimation from the model was also consistent and had a normal distribution. The ARDL model is an Infiniti Distributed Lag model that is more flexible and parsimonious. This model is an alternative to the Koyck Scattered Lag model and the Polynomial Scattered Lag model. Koyck's Scattered Lag Model is faced with a serial correlation problem that leads to estimation using OLS not only being biased but even becoming inconsistent. The Polynomial Distributed Lag Model provides a solution to this problem, but this method requires strong assumptions related to the structure of the deferred weights as well as the appropriate deferred selection. The ARDL model framework will be used in constructing boundary tests to test the existence of cointegration in the variables used. The ARDL model is a linear time series model in which both the dependent and independent variables are related not only to the current period but also cover values in the past (deferred) time. Using this method, the data analysis could provide evidence to support the study (Rizaudin Sahlan, 2021).

\section{Suggestions}

Policy Implications: When Wagner's Law is successfully proven, then the government needs to be careful with increasing spending and use that spending as a policy planning tool (Salih, 2012). Moreover, increased government spending relative to economic growth, in the long run, will reduce funds or allocations for more beneficial spending when such spending is followed by debt (Grullon, 2014). Therefore, if Wagner's Law can also be proven, then the government needs to reduce spending that has less impact on economic growth, such as subsidies (Srinivasan, 2013). If the Keynesian Theory is proven, then this thing is good for economic growth. However, this increase in government spending is necessary for important sectors or components such as infrastructure, education, and health that can boost economic growth in the long run. It can be concluded that when Wagner's Law can be proved, this shows that government spending is passive and if the Keynesian Theory is successfully proved, then such government spending is active. If there is a two-way relationship, then the government must decide on the policy implications. If the results of the study are neutral, this indicates that government spending is not a contributor to economic growth (Dogan and Tang, 2006). Finally, a developing country like Malaysia needs a lot of spending to stimulate economic growth. 


\section{Conclusion}

This study can guide policymakers, especially the government, in planning the national budget and continuing to improve the country's economic growth. Each macroeconomic variable is vulnerable to any shocks that occur, and specific measures can be implemented to deal with crises of economic turmoil and recession. Apart from focusing on spending, the government also needs to be sensitive to any variables related to international trade, such as imports and exports, as Malaysia is a country that is dependent on the sector. Furthermore, the effect of the interaction between the two variables can provide an idea of whether the two variables support economic growth or not. This is because an increase in growth can drive the development of a more sustainable and competitive country in the future.

\section{References}

Abdullah, H. \& Maamor, S. (2010). Relationship between national product and Malaysian government development expenditure: Wagner's law validity application. International Journal of Business and Management, 5(1).

Afonso, A. \& Alves, J. (2016). Reconsidering, Wagner's law: Evidence from the functions of the government. Lisbon School of Economics and Management, 1466-4291.

Antonakakis, N., Cunado, J., Filis, G. \& Fernando, P. D. G. (2017). Oil dependence, quality of political institutions and economic growth, 53, 147-163.

Bank Negara Malaysia. (1998). Bank Negara Malaysia annual report 1998.

Bank Negara Malaysia. (2020). Perkembangan ekonomi, monetari dan kewangan pada tahun 2020. Bank Negara Malaysia.

Choong, C. K., Baharumshah, Z. A., Yusop, Z. \& Habibullah, S. M. (2010). Private capital flows, stock market and economic growth in the developed and developing countries: A comparative analysis. Japan and the World Economy, 22, 107-117.

Dada, M. A. \& Adewale, O. A. (2013). Is Wagner's law a myth or a reality? Empirical evidence from Nigeria. International Journal of Development and Economic Sustainability, 1, 123-137.

Dogan, E. \& Tang, T. C. (2006). Government expenditure and national income: Causality test for five southeast Asian countries. International Business \& Economics Research Journal, 5.

Furuoka, F. \& Harvey, H. (2014). Wagner's law in Brunei: New findings. Malaysian Journal of Business and Economics, 1, 89-102.

Grullon, S. (2014). National income and government spending: Co-integration and causality results for selected Latin American countries. International Journal of Economics, Commerce and Management, 2, $1-9$.

Hakimah, N. Nor, M., Low, L. S. W. \& Mohd Nor, S. A. (2014). Foreign direct investment, economic growth, and quality of stock market development - panel analysis. Proceeding of PERKEM 9 ${ }^{\mathrm{TH}}$ (pp. 571-581). Universiti Kebangsaan Malaysia.

Jespersen, J. (2005). Introduction to macroeconomic theory. Djoef Publishing London.

Kaharudin, H. I., Abd Karim, Z. Zaidi, S. A. \& Ismail, A. M. (2017). The effect of fiscal policy on private expenditure: A SVAR analysis in Malaysia. Malaysian Journal of Economics, 51, 89-106.

Kamus, D. (2005). Dewan Bahasa dan Pustaka.

Kogid, M., Mohd Nor, S. A., Sarmidi, T. \& Loganathan, N. (2012). Long-term relationship and dynamic interactions between stock markets and economic activities in Malaysia. Journal of Management, 36, 149-160.

Kumar, S., Webber, D. \& Fargher, S. (2012). Wagner's law revisited: Cointegration and causality test for New Zealand. Applied Economics, 607-616.

Mohammadi, H. \& Rati, R. (2015). Economic development and government spending: An exploration of Wagner's hypothesis during fifty years of growth in east-Asia. Economies 2015, 3,150-160.

Moradbeigi, M. \& Law, S. H. (2017). The role of financial development in the oil-growth nexus. Resources Policy, 53, 164-172.

Norazrin, A. S. (2018). Hubungan dinamik antara pemboleh ubah interaksi dan perdagangan antarabangsa terhadap pertumbuhan ekonomi di Malaysia. Tesis Sarjana. Universiti Pendidikan Sultan Idris. 
Pesaran, M. H., Shin, Y. \& Smith, R. (2001). Bounds testing approaches to the analysis of level relationships. Journal of Applied Econometrics, 16, 289-326.

Rambeli, N., Dayang, A. A. M. \& Emilda, H. (2016). The effect of foreign direct investment, export, and employment on economic growth model. International Journal of Academic Research in Business and Social Sciences, 6(11).

Ramlan, K. W., Sulaiman, N. \& Liew, C. S. (2011). Pertumbuhan ekonomi dan pengurangan kemiskinan di Malaysia: Satu pendekatan dinamik. Proceeding of PERKEM VI, 1, 482-491.

Rosli, R., Abdul Talib, B. \& Mohd Noor, A. M. (2014). Urus tadbir ekonomi yang adil: Ke arah ekonomi berpendapatan tinggi. The $9^{\text {th }}$ Malaysian National Economic Conference. Kuala Terengganu.

Sahlan, R. (2021). Ekonometrik moden dengan aplikasi stata. Penerbit Universiti Utara Malaysia.

Salih, M. A. R. (2012). The relationship between economic growth and government expenditure: Evidence from Sudan. International Business Research, 5, 40-46.

Salwindi. N. \& Seshamani. V. (2016). The relevance of Wagner's law to Zambia. International Review of Research in Emerging Markets and the Global Economy (IRREM), 2, 808-822.

Samudram, M., Nair, M. \& Vaithilingam. S. (2008). Keynes and Wagner on government expenditure and economic development: The case of a developing economy. Empir Econ, 36, 697-712.

Sarel, M. (1996). Nonlinear effects of inflation on economic growth. IMF Staff Papers, 43, 199-215.

Sari, A. C. P. \& Kaluge, D. (2017). Analisis faktor-faktor yang mempengaruhi pertumbuhan ekonomi ASEAN member countries pada tahun 2011-2016. Jurnal ilmiah Bisnis dan Ekonomi Asia, 11, 24-29.

Sharma, S. D. (2003). The Asian Financial Crisis: Crisis, reform, and recovery. Manchester University Press.

Toh, K. S., Jusoh, M. \& Sarmidi, T. (2010) Inflation threshold and economic growth in Malaysia. $5^{\text {th }}$ Malaysian National Economic Conference, 1, 83-97.

Sinha. P. (2007). Does the Wagner's law hold for Thailand? A time-series study. Munich Personal RePec Archive (MPRA), 2560.

Srinivasan, P. (2013). Causality between public expenditure and economic growth: The Indian case. International Journal of Economics and Management, 7, 335-347.

Verma, S. \& Arora, R. (2010). Does the Indian economy support Wagner's law? An econometric analysis. Eurasian Journal of Business and Economics, 3, 77-91.

World Bank. (2018). World Development Indicators. World Bank. https://www.data.worldbank.org/

Yudistira, H. P. \& Gek, S. M. J. W. (2014). Testing the existence of Wagner's Law and government expenditure volatility in Indonesia post-reformation era. Journal of Economics and Sustainable Development, 5, 130-140. 